\title{
$\mathrm{RC}$ 部材端部におけるコンクリートの圧縮特性と曲げ耐力 COMPRESSIVE PROPERTIES OF CONCRETE AND FLEXURAL STRENGTH AROUND CRITICAL SECTION OF REINFORCED CONCRETE MEMBERS
}

\author{
今井和 正*, 是永健好**, 瀧口克已*** \\ Kazumasa IMAI, Takeyoshi KORENAGA and Katsuki TAKIGUCHI
}

\begin{abstract}
It is known that the prediction of the flexural strength of reinforced concrete columns on the basis of confined concrete stress block is conservative. The purpose of this research is to propose a method in which the flexural strength can be calculated accurately. Stress-strain relationship of concrete around the end of columns is presumed based on the results of compression test, and the flexural strength is calculated on the basis of the stress block. It is compared with previous experimental results of reinforced concrete columns and the validity of the calculation method is confirmed. Some factors are assumed to be variables, and numerical calculation is conducted. Main factor that influences the flexural strength is extracted, and abbreviated calculation method is proposed.
\end{abstract}

Keywords : reinforced concrete, end of members, flexural strength, compressive strength, confinement, critical section 鉄筋コンクリート, 部材端部, 曲げ耐力, 圧縮強度, 拘束, 危険断面

1. はじめに

鉄筋コンクリート柱（以下， RC柱と略す）の曲げ酎力を断面計算 で求める場合，軸力比が高いほど実験結果が過小評価されることが 知られている例えばり。これは建物の設計上必ずしも安全側の結果を もたらすものではなく，例えば柱のせん断破壊に対する安全性を検 討する場合や当該柱が接続する接合部や梁部材の設計時などには, 曲け耐力下限值の算定式のみでは設計資料として不十分である。こ うした場合への対処として，鞄性保証型設計指針2〉では実験の平均 值を評価できるGheeらの提案式”が紹介され，高軸力下の曲げ上限 強度算定時の指標に用いられている。New RCプロジェクトの報告書 3) では，この傾向が横補強筋の拘束効果(コンクリートの強度上昇 と勒性改善) を考慮した場合にも見られること, 軸力比を変数とし た二次関数で実験での傾向を表現できることが述べられている。し かしながら，いずれの提案でも曲げ耐力上昇のメカニズムが明確に されていないため, 部材諸元（材料強度, せん断スパン比, 鉄筋量 など）の影響が定量的に評価されておらず，その妥当性が十分に確 認されているとは言い難い状況にある。

田中らは，部材が取り付く接合部（コンクリートブロック）から の付加拘束によって材端近傍のコンクリート強度が上昇し, 危険断 面位置が接合部フェースから移動することが曲け耐力上昇の原因であ ると捉え，危険断面位置を中立軸深さと関連付けて検討している( 堀田らは, 田中らと同じ耐力上昇のメカニズムを想定し，三軸応力
下の構成則を用いた有限要素解析により危険断面の移動と曲げ耐力 の上昇を再現している゙う。これらの実験的および解析的研究により メカニズムの妥当性は確認されているが, 部材諸元の影響をパラメ トリックに検討した例はない。

一方，滝口らは純曲げを受ける柱と逆対称曲げを受ける柱の実験 結果から，後者の方が高い曲げ耐力が得られることを示し，この原因 をコンクリートの圧縮特性の違いによるものと推定している6) -9)。 後者の場合, 実験結果から推定される材端コンクリートのストレ゙ス ブロックは，応力の大きさを表す形状係数 $k_{\text {max }}$ (文献3)などでは $k_{3}$ ) が1以上となり，Hognestadの純曲げ実験結果10)をもとにACI318規準 11)で定められた值より大きいこと，この結果は軸力比に影響されな いこと，横補強筋による拘束効果のみが原因ではないことなどを報 告しているが，係数の算定式提案には至っていない。

本研究では，高軸力を受ける柱も含めて，RC部材の曲げ耐力を精

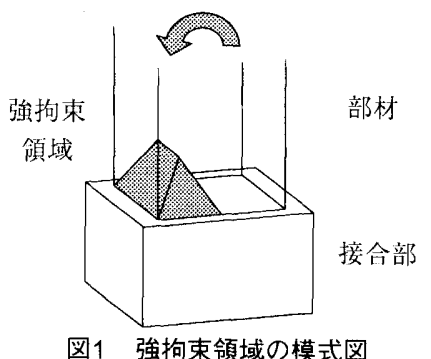

* 大成建設侏技術センタ一建築技術研究所 亡修

** 大成建設(侏)技術センタ一建築技術研究所 博上:(些術工学)

*** 東京工業大学: 教授・土博
Building Engineering Research Institute, Technology Center, Taisei Corporation, M. Eng.

Building Engineering Research Institute, Technology Center, Taisei Corporation, Dr. Design Prof., Tokyo Institute of Technology, Dr. Eng. 
度良く推定できる手法の構筑を目的としている。耐力上昇のメカ二 ズムとして田中ら ${ }^{4)}$, 堀田ら ${ }^{51}$ と同様に接合部からの付加拘束の影 響を想定し, 図1に示す強拘束領域を設定する。同領域内のコンク リートの応力ーひずみ関係を実験結果に基づいて推定し，ストレス ブロックに置換して曲げ耐力を算定する。既往の実験結果との比較 によりその妥当性を確認した上で，主要な諸元を変数としたパラメ トリックスタディを行い，耐力上昇に影響する因子を抽出して略算 式の提案を試みる。

なお，本論文では，柱に取り付く比較的大きな体積を有する部分（実 験では加力スタブに相当）を接合部と呼ぶこととする(図1参照）。

\section{2. 強拘束コンクリートの応カーひずみ関係の推定}

\section{1 強拘束領域}

是永らはプレストレストコンクリート梁の曲げ解析に扔いて，梁 端部に強拘束領域を仮定し，領域内コンクリートのモデルとして完 全弾性の応力一ひずみ関係を設定している(2)。これは堀田らが有限 要素解析で取り入れた接合部からの付加拘束による厄縮強度の上昇 5)を単純化したものと考えられる。本論文でも同様の強拘束領域を仮 定するが，曲げ圧縮の卓越する柱部材を対象とするために，是永らと は異なり，㔄性低下と応力低下を表現できる応力ーひずみ曲線を設定 することとした。

\section{2 圧縮実験の概要}

強拘束コンクリートの応力ーひずみ関倸を実験的に把握するのは 困難である。通常行われるシリンダー試験体の庄縮実験では，高さ 中央付近に破壊が集中して上下端面付近は弾性範囲に留まるからで ある。一方，シリンダー試験体における縮強度（最大荷重を断面 積で除した値）は，供試体の高さと直径の比が小さいほど离くなる ことが知られており 13 - -15) なと，載荷板からの拘束によってコンクリー トが三軸応力状態となることがその原因と考えられているは市ど。本 研究ではこの実験事実を利用して, 強拘束コンクリートの応力ーひ ずみ関係の推定を試みる。

表1 圧縮実験の試験体一覧

\begin{tabular}{|c|c|c|c|c|c|}
\hline \multirow{2}{*}{ 試験休名 } & \multirow{2}{*}{ 載荷面 } & \multirow{2}{*}{$\begin{array}{l}\text { 目標強度 } \\
\left(\mathrm{N} / \mathrm{mm}^{2}\right)\end{array}$} & \multirow{2}{*}{$\begin{array}{l}\text { 高导 } \\
\text { 直往 }\end{array}$} & \multicolumn{2}{|c|}{ 鼠人伈) ${ }^{*}\left(\mathrm{~N} / \mathrm{mm}^{2}\right)$} \\
\hline & & & & 実験优 & 敦算值 \\
\hline A30-0.5 & \multirow{12}{*}{ 鋼板 } & \multirow{4}{*}{$\begin{array}{c}30 \\
(\mathrm{~W} / \mathrm{B}=60 \%)\end{array}$} & 0.5 & 60.3 & 62.5 \\
\hline A $30-1.0$ & & & 1.0 & 41.0 & 37.6 \\
\hline $\mathrm{A} 30-1.5$ & & & 1.5 & 33.3 & 34.8 \\
\hline $\mathrm{A} 30-2.0$ & & & 2.0 & 34.8 & 34.8 \\
\hline $\mathrm{A} 100-0.5$ & & \multirow{4}{*}{$\begin{array}{c}100 \\
(\mathrm{~W} / \mathrm{B}=33 \%)\end{array}$} & 0.5 & 120 & 118 \\
\hline $\mathrm{A} 100-1.0$ & & & 1.0 & 99.6 & 97.7 \\
\hline A100-1.5 & & & 1.5 & 94.3 & 97.7 \\
\hline $\mathrm{A} 100-2.0$ & & & 2.0 & 97.7 & 97.7 \\
\hline A150-0.5 & & \multirow{4}{*}{$\begin{array}{c}150 \\
(\mathrm{~W} / \mathrm{B}=17 \%\end{array}$} & 0.5 & 164 & 154 \\
\hline $\mathrm{A} 150-1.0$ & & & 1.0 & 148 & 136 \\
\hline A $150-1.5$ & & & 1.5 & 137 & 136 \\
\hline A150-2.0 & & & 2.0 & 136 & 136 \\
\hline $\mathrm{B} 30-0.5$ & \multirow[t]{14}{*}{ コンクリート } & \multirow{4}{*}{$\begin{array}{c}30 \\
(\mathrm{~W} / \mathrm{B}=60 \%)\end{array}$} & 0.5 & 57.3 & 56.0 \\
\hline B30-1.0 & & & 1.0 & 37.1 & 31.0 \\
\hline B30-1.5 & & & 1.5 & 30.5 & 27.2 \\
\hline $\mathrm{B} 30-2.0$ & & & 2.0 & 27.2 & 27.2 \\
\hline $\mathrm{B} 100-0.5$ & & \multirow{5}{*}{\begin{tabular}{c|}
100 \\
$(\mathrm{~W} / \mathrm{B}=33 \%)$
\end{tabular}} & 0.5 & 127 & 112 \\
\hline $\mathrm{B} 100-1.0$ & & & 1.0 & 106 & 91.7 \\
\hline B100-1.5 & & & 1.5 & 94.2. & 91.7 \\
\hline $\mathrm{B} 100-2.0$ & & & 2.0 & 91.7 & 91.7 \\
\hline $\mathrm{B} 100-3.0$ & & & 3.0 & 94.3 & 91.7 \\
\hline B $150-0.5$ & & \multirow{5}{*}{$\begin{array}{c}150 \\
(\mathrm{~W} / \mathrm{B}=17 \%\end{array}$} & 0.5 & 151 & 161 \\
\hline B $150-1.0$ & & & 1.0 & 149 & 143 \\
\hline B $150-1.5$ & & & 1.5 & 143 & 143 \\
\hline B150-2.0 & & & 2.0 & 130 & 143 \\
\hline B150-3.0 & & & 3.0 & 143 & 143 \\
\hline
\end{tabular}

応力ーひずみ関係の推定に用いる圧縮実験 ${ }^{17)}$ の概要を述べる。試 験体は直径 $150 \mathrm{~mm}$ の円筒形プレーンコンクリートで，表1に示すよ うに強度および「高さ/直径」をパラメータとした。Aシリーズで は鋼板を介して載荷し，Bシリーズでは実部材の端面条件を想定し て試験体上下に設置したコンクリート製ブロックを介して載荷した (図2参照)。Bシリーズ試験体は下唄ブロックの打設・硬化徯, 試 験区間と上側ブロックを連続的に打設して製作されている。下側ブ ロックの打ち継ざ面は金ゴテにより平滑化した。両シリーズとも目 標強度を $30,100,150 \mathrm{~N} / \mathrm{mm}^{2}$ の 3 水準とし，それぞれ表2に示す調 合とした。目標強度が $100,150 \mathrm{~N} / \mathrm{mm}^{2}$ のコンクリートには，普通ポ ルトランドセメント，スラグ石高扔よびシリカフェームを混合した 三成分結合材を用いた。

実験で得られた最大応力を表1内に示す。高さ/直径が小さいほど最 大応力が高いこと，その強度上屍は高強度領域では比較的小さいこと が分かる。また，端面条件の違いによる明確な差異は見られない。い ずれの試験体に执いても，高さ中央近傍のコンクリートが压壤，剥落 し，上下端面を底面とする錘状の部分が残存した。Bシリーズ試験体 の上下で端面条件が異なる（1. 側：ブロックと…体打設，下側：打ち 継ぎことによる破壊性状の明確な差異は見られなかった。

な㧍，B150-2.0試験体の最大纫力车験值が他と比べて極端に小さ くなっているのは，試験体製作時または加力実験時に生じた何らか の精度䛊等が原因と考えられる。次節では高さ/直径 2.00 試験体 の強度を基準傎 $f^{\prime}$ として做いるが，B150シリーズではこれの代わ りにB150-3.0試験体の結果 $\left(143 \mathrm{~N} / \mathrm{mm}^{2}\right)$ を用いる。

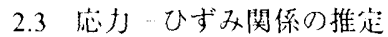

図2に亦与ように、コンクリート供試体を端面からの付加拘束の 影響を受ける強拘束領域と缃迅領域の 2 つに分けて考之，供試体端 面を底面とした円錐部分を強拘束領域と定義する。強拘束コンク リートは鋼板またはコンクリート製ブロックによって，端面を介し て周方向の膨張を拘束される。三軸応力状態となることにより，横 補強筋による拘束コンクリートと同様のメカニズムで圧縮強度が上

表2 コンクリートの調合

\begin{tabular}{|c|c|c|c|c|c|}
\hline 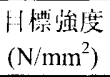 & $\begin{array}{c}\text { 水結合材比 } \\
(\%)\end{array}$ & $\begin{array}{l}\text { 結合材 } \\
\left(\mathrm{kg} / \mathrm{m}^{3}\right)\end{array}$ & $\begin{array}{c}\text { 水 } \\
\left(\mathrm{kg} / \mathrm{m}^{3}\right)\end{array}$ & $\begin{array}{l}\text { 粗䎡㤔 } \\
\left(\mathrm{kg} / \mathrm{m}^{3}\right)\end{array}$ & $\begin{array}{l}\text { 綀骨材 } \\
\left(\mathrm{kg} / \mathrm{m}^{3}\right) \\
\end{array}$ \\
\hline 30 & 60 & $283^{* 1}$ & 170 & 982 & 853 \\
\hline 100 & 33 & $485^{* 2}$ & 160 & 865 & 872 \\
\hline 150 & 17 & $882^{* 2}$ & 150 & 865 & 572 \\
\hline
\end{tabular}

*1 普通ポルトランドせメン

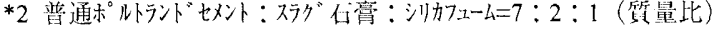
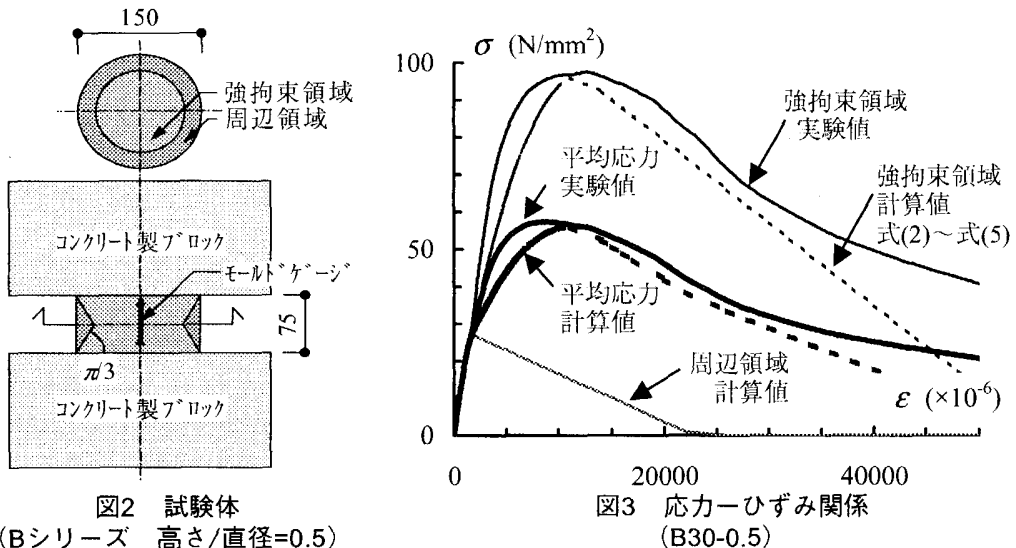

(B30-0.5) 
昇し，圧縮勒性が向上すると考えられる。

表1に示した最大応力実験結果によれば，高さ/直径による影響は 「高さ/直径 $\geqq 1.5 」$ の場合は明確ではなく，「高さ/直径 $1.0 」 の$ 場合に顕著となっている。この結果から, 円錐の底角はおおむね $\pi / 3$ 以下で $\pi / 4$ より大きな值に設定すべきと考えられる。ここでは 底角を $\pi / 3$ と仮定し, その妥当性は計算による平均応力ーひずみ関 係を実験結果と比較することで検証する。

実験では全断面の荷重が計測されているので，この全体荷重から 周辺コンクリートの負担荷重を差し引いて強拘束コンクリートの負 担荷重を推定し, 強拘束領域の断面積で除して負担応力を求める。 高さ/直径 $=2.0$ の試験体の中央断面では強拘束領域が存在しないた め, その実験結果を評価できる応力ーひずみモデルを周辺コンク

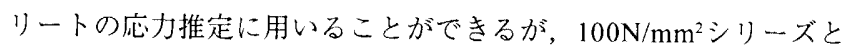
$150 \mathrm{~N} / \mathrm{mm}^{2}$ シリーズでは高さ/直径 $=2.00$ 試験体で脆性的な破壊が生 じてモデル化に不可欠な㐫力下降域のデータが得られなかったた め, 対象から除外した。また, 全断面に対する強拘束領域の面積比 率が小さいと強拘束コンクリートの応力推定精度が著しく低下する ので，その比率が最も大きなB30-0.5試験体をモデル化の対象とした (A30-0.5試験体はモールドゲージの断線によりひずみデー夕が得ら れなかった）。B30-0.5試験体の平均応力ーひずみ関係を図3に示す (平均応力実験值)。ひずみは試験体中央のモールドゲージによる 計測值である。

周辺コンクリートの応力を推定するため, B30-2.0試験体の実験結 果を評価しうる数式モデルを設定した（図3の周辺領域計算値）。試 験体に用いたコン,クリートは六車・渡邊らの提案によるプレーンコン クリートのモデル19\} (図4参照)に比べて応力下降勾配が緩やかで あったので, 点Bを六車・渡傻モデルの定義に従い実験結果から設定 した。また，六車・渡邉モデルでは点Cのひずみが $2 \%$ とれている が, 同様の理由により点B以降はABの延長線上を推移するモデルと
した。なお，点Bは六車・渡邊モデルでプレーンコンクリートの曲げ 圧縮限界時として定義されている点である。

周辺コンクリートの負担荷重を全体荷重から差し引いて推定した 強拘束コンクリートの応力ーひずみ関係実験結果を図3に示す（強拘 束領域実験值）。この結果をもとに，六車·渡邊らの拘束コンクリー トモデル19）をベースとして（図4参照），強拘束コンクリートのモ デル化を行う。図4の点D抢よび点Eは拘束コンクリートの最大応力 時および曲げ压縮限界時としてそれぞれ定義されている点である。 本論文で扱う強拘束コンクリートも前述のように一種の拘束状態に あると考えられるので，実験結果をもとにこれらの特性点を設定す ることで, 強拘束コンクリートの芯力ーひずみ関係として読み替え

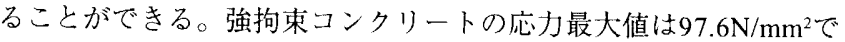
あり，コンクリート強度 $\left(\mathrm{B} 30-2.0: 27.2 \mathrm{~N} / \mathrm{mm}^{2}\right)$ の約3.6倍であっ た。一方, 六車·渡邊モデル19)では, 横補強筋の拘束効果による強 度上昇は式(1)で与えられている。

$$
\sigma_{c m} / f_{c}^{\prime}=1+150 C_{c}
$$

$$
\text { ここで, } f_{c}^{\prime}: \text { プレーンコンクリートの压縮強度 }
$$

$\sigma_{c m}:$ 拘束コンクリートの圧縮強度

$C_{c}$ : 横補強筋による拘束係数（横補強筋の強度, 量求 よびコンクリート強度などから定められる)

上記の強度上昇も一種の拘束効果と考えてその上昇率から係数 $C_{c}^{\prime}$ を 求めると0.017となる。参考までに，この拘束係数は円形断面コンク リート柱を体積比 $4 \%$ 程度の異形PC鋼棒（SBPD 1275/1420）で補強 した場合に相当する。 $C_{c}$ と同様に $C_{c}^{\prime} か ゙ f_{c}^{\prime}$ に反比例するものとし て, 式(2)で $C_{c}^{\prime}$ を設定する。

$$
\begin{aligned}
& C_{c}^{\prime}=0.017\left(27.2 / f_{c}^{\prime}\right)=0.46 / f_{c}^{\prime} \\
& \sigma_{c m}^{\prime} / f_{c}^{\prime}=1+150 C_{c}^{\prime}
\end{aligned}
$$

ここで, $C_{c}^{\prime}$ : 端面からの付加拘束の効果を表す保数 $\sigma_{c m}^{\prime}:$ 強拘束コンクリートの圧縮強度

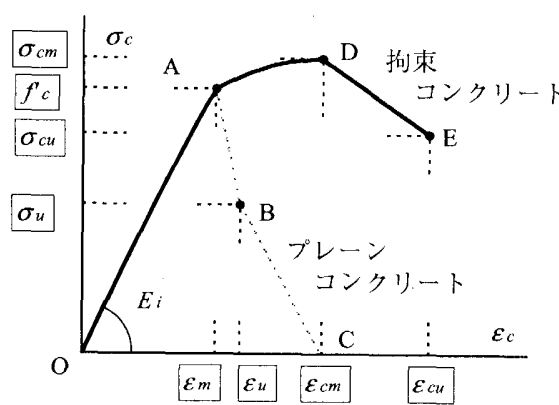

図4 コンクリートの応カーひずみ関係 (六車·渡邊モデル19)

$$
\sigma \max / f^{\prime} c
$$

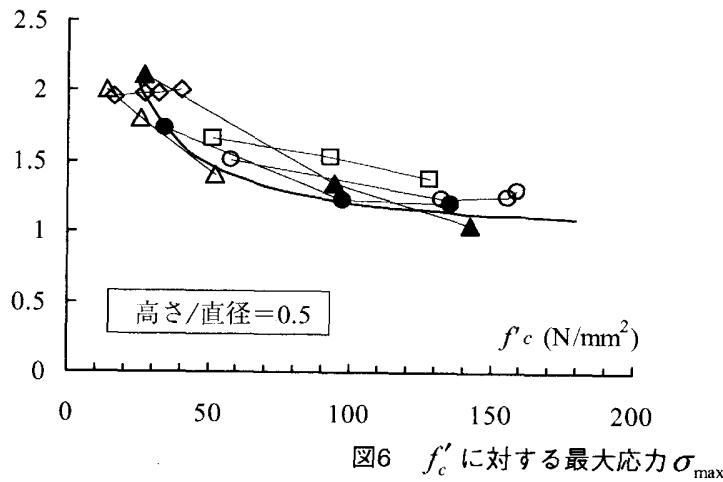

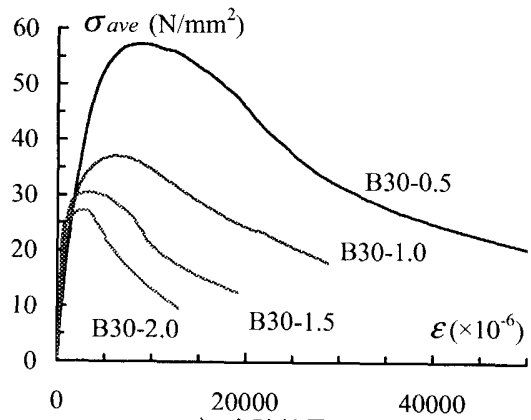

a) 実験結果

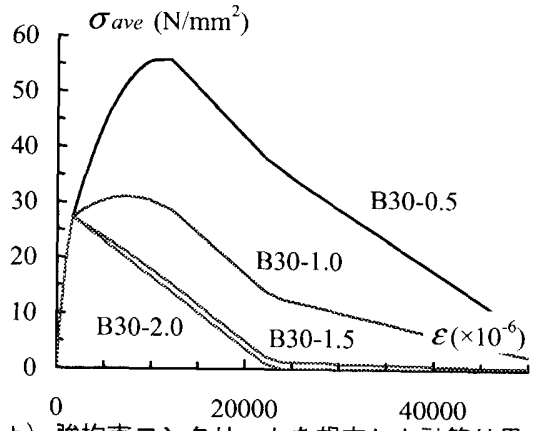

b）強拘束コンクリートを想定した計算結果

5 平均応カーひずみ関係の実験結果と計算結果（B30シリーズ）

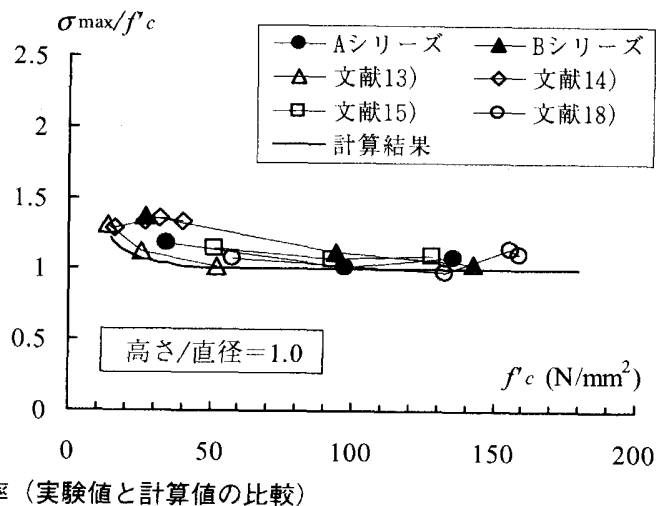


応力一ひずみ関係を定める特性点（最大応力時, 曲げ圧縮限界時） のひずみを, 六車·渡櫋モデル(9) と同一の式形状で表すと, 式(4), 式(5)となった。両式の左辺は, B30-0.5試験体の強拘束コンクリー トの応力ーひずみ関係（図3の強拘束領域害験値）と, B30-2.0試験体 の結果から設定した周辺コンクリートの応力ーひずみ関係（図3の周 辺領域計算値）の特性值の比である。

$$
\begin{aligned}
& \varepsilon_{c m}^{\prime} / \varepsilon_{m}=1+370 C_{c}^{\prime} \\
& \varepsilon_{c u}^{\prime} / \varepsilon_{u}=1+170 C_{c}^{\prime}
\end{aligned}
$$

$$
\text { ここで, } \varepsilon_{m}, \varepsilon_{u} \text { : プレーンコンクリートのf } f_{c}^{\prime} \text { 時ひずみおよび }
$$

曲げ圧縮限界ひずみ

$$
\begin{gathered}
\varepsilon_{c m}^{\prime}, \varepsilon_{c u}^{\prime} \text { : 強拘束コンクリートの } \sigma_{c m}^{\prime} \text { 時ひずみおよび } \\
\text { 曲げ压縮限界ひずみ }
\end{gathered}
$$

なお，強拘束コンクリートの曲げ压縮限界時応力 $\sigma_{c u}^{\prime}$ は，六車・渡邊 モデル19iの定義により $\varepsilon_{c u}^{\prime}$ から求められる。式(4), 式(5)と六車・渡邊 らの円形断面を対象としたモデル191を比較すると，強拘束領域の $\varepsilon_{c m}^{\prime}$ と $\varepsilon_{c u}^{\prime}$ は，拘束係数が同一の場合の拘束領域の値より小さい。

式(2)〜式(5)から得られる強拘束コンクリートの応力ーひずみ関係 を図3中に示す（強拘束領域部算值）。この䊅果と周辺領域計算値 から求まる全断面の平均态力計算值を同図中に示す。また，B30シ リーズの平均応力ーひずみ関倸の計算結果を実験結果と比較して図 5 に示し，全試験体について求めた平均応力の最大値を表1中に心 す。な㧍, 小室・今井らは， $f^{\prime} か ゙ 100 \mathrm{~N} / \mathrm{mm}^{2}$ を超える超高强度コンク リートでは，带筋による拘束効果が普通強度の場合と分量的に異な ることを報告している201が，本実験では強拘束領域の特性が得られ ていないので同－の式で表現した。ただし，㓓辽コンクリートにつ いては文献20）のモデルを使用した。表1および図5から，提案した 強拘束コンクリートの応力ーひずみ関係を用いることにより，2.2節 で述べた実験結果の傾向を打拉む再現できていることが分かる。 本実験と同様に高さ/直径をパラメータとした压縮実験 ${ }^{3}$ ) -15)，187 の結果を計算結果と比較して図6に示す。図は高さ/直径 $=0.5,1.0$ の試験体を対象として掞り, 縦軸は最大応力実験值 $\sigma_{\text {max }}$ の $f_{c}^{\prime}$ に対す る比を示している。限られた実験データではあるが, 端面拘束による 圧縮強度上昇が $100 \mathrm{~N} / \mathrm{mm}^{2}$ を超える超高強度コンクリートも含めて適 切に評価できており, 図2に示した強拘束領域の範囲とその応力一ひ ずみ関係の設定は扮扔むね妥当なものと判断できる。

\section{3. ストレスブロックによる曲げ而力の検討}

\section{1 曲け酎力算定法}

2 章で設定した強拘束コンクリートの応力ーひずみ関係を矩形ス トレスブロックに置換し， RC柱の曲げ耐力を算定する。対象試験

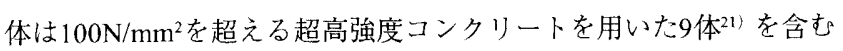
計44体211-26) である。文献中で曲げ破壊以外のモードと報告されてい るものと，主筋のひずみ硬化による耐力上昇が報告されているものは 対象から除外した。対象試験体のコンクリート強度は23.2〜173N/ $\mathrm{mm}^{2}$, 女ん断スパン比は1.25 2.5, 主筋比は1.6 4.4\%, 帯筋比は $0.4 \sim 1.6 \%$, 軸力比は $0.23 \sim 0.91$ の範囲にある。

断面の曲け耐力は，図7に示すようにa)かぶり部を含む全断面の 耐力, $b$ )エアのみの耐力の 2 通りについて平面保持解析により求 め，その大きい方を計算值とした。a)の場合にも拘束領域と強拘束 領域は存在すると考えられるが，圧縮縁が終局ひずみに達したとき

の内部コンクリートは，大きな強度上昇が生じる程のひずみに達し ないので, 文献3）と同様に全領域をプレーンコンクリートとして 扱った。b）の場合は带筋による拘束効果を文献20），27）から求ま るストレスブロックで表現し, 強拘束領域では式(2)〜式(5)から求ま るストレスブロックの応力増加分をこれに累加して評価した。各領 域のストレスブロックの形状係数と終局ひずみは, 文献3）や21）と

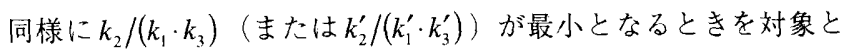
し，文献21）を参考にして数值計算により設定した。強拘束領域 は，スタブフェースの压縮領域を底面として底角を $\pi / 3$ とする五面体 (図1㧍よび図7b)参照) とした。主筋の応力一ひずみ関係は完全弾 塑性とした。

強拘束領域の存在により生ずる危険断面の移動と曲げ耐力の上昇 を図8に示す。これは田中ら4の考え方を其体的に示したものであ る。コア耐力を算定する場合は，断面が潜在的に保有している曲げ耐 力は离さ力向に一定ではなく端部付近で曲線状に増大するため（図 8b)），入力モーメントの分布を想定すれば（図8a)），雨者が接する ときに材端モーメントが最大となり，接点位置が危険断面となる（図 8c)）。ここでは，强拘束領域を仮定した五面体の範国を高さ方向に 50 等分して各断面での酎力を求め, 危険断面位置と曲げ酎力を算定し

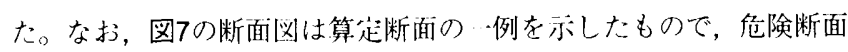
位㯰を意网したものではない。图70)a)かぶり部を含む断䤄耐力は高

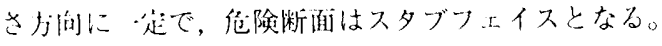

3.2 荑験結果との比較

曲げ耐力の叶算低に対する先験值の比を図9に示す。軸力比 $n$ $\left(=N / h D f_{c}^{\prime}\right.$ 。Nは柱軸力， $h, D$ は柱の断面はば扩よびせい)のみが
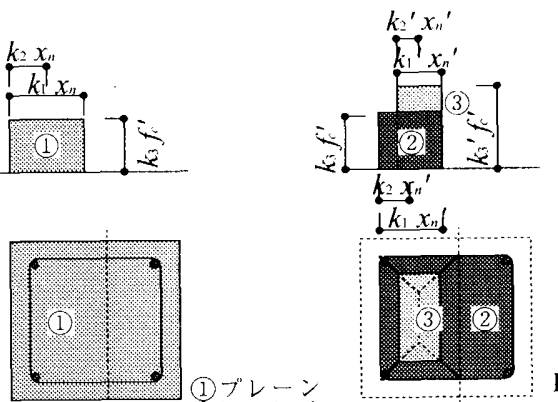

$\mathrm{B}^{\mathrm{B}} \mathrm{B}^{\prime}$ 断面
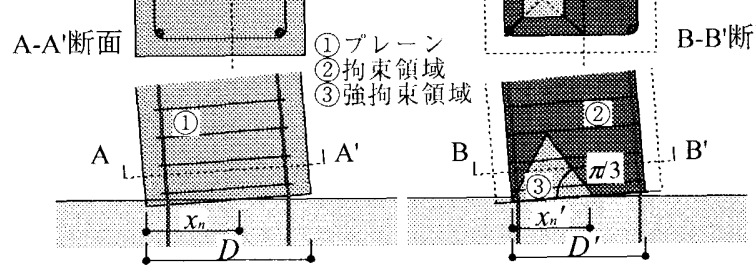

a) 全断面耐力算定時 $\quad$ b) コア耐力算定時 図7 強拘束領域を考慮したストレスブロック

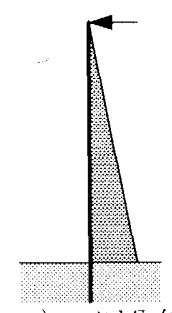

a) モーメント分㭁

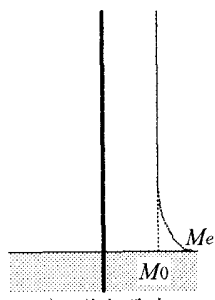

b) 酎方分布

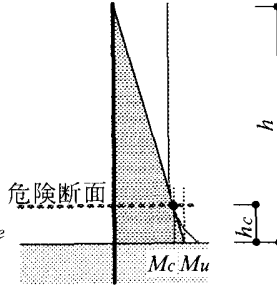
c) 危険断面位置と

$M 0 ：$ 強拘束領域を考虑しない場合の終局耐力 $M e:$ 材端の終局耐力（強拘束领域を考慮）

$M_{c}$ ：危険断面の終局耐力 (強拘束領域考慮)

$M_{u}$ : 材端の終局時モーメント（強拘束頱域を考虑） 図8危険断面の移動と曲げ而力の上昇 
異なるデータを直線でつないで示した。また， $n$ をパラメータとし た実験シリーズ（文献22），21））の曲け耐力一軸力比相関曲線の 比較を図10に示す。図100曲げ耐力はせん断力を全断面で除して求 めた平均せん断応力で表した。文献21）の実験では，かぶり圧壊時 とその後の変形増大時に 2 回の荷重ピーク值が得られているので, その双方を図10に示した。横補強筋の拘束効果271のみを考慮した場 合には，文献1）～3）での報告と同様に軸力比が高いほど過小評価 となっており，文献3）に示されている補正式と同様の傾向が見られ るが，強拘束コンクリートを考慮した場合にはその傾向が見られな くなっている。また, これらの試験体では大半がかぶりコンクリー 卜の圧壊後も耐力が上昇して最大耐力に達したことが報告されてお り，本手法ではこの事実と扮扮むね一致した結果が得られている。

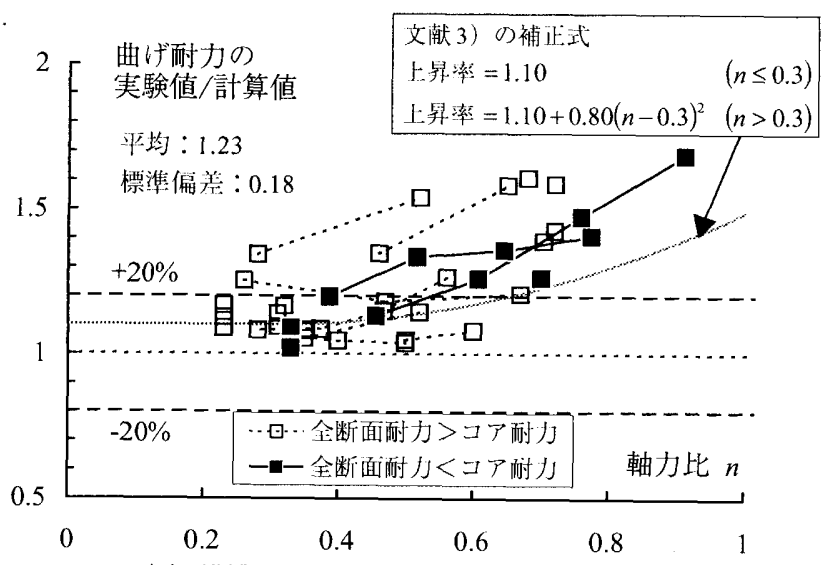

（1）横補強筋の拘束効果のみを考慮した場合

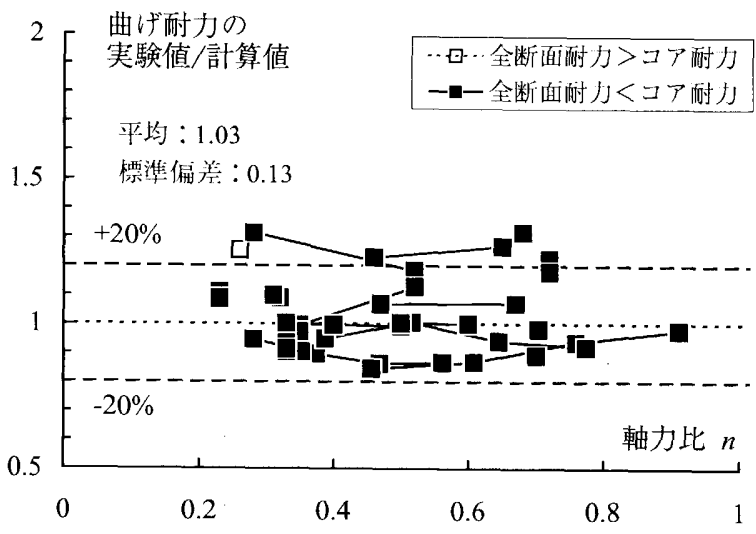

（2）強拘束コンクリートを考虜した場合

図9曲げ耐力の実験值／計算值と軸力比の関係
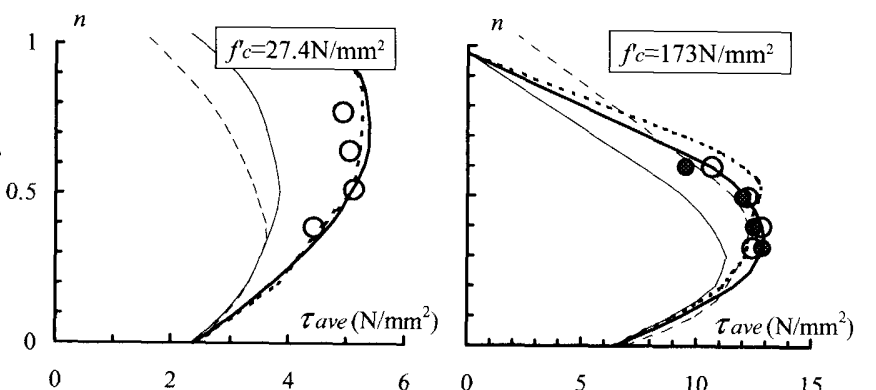

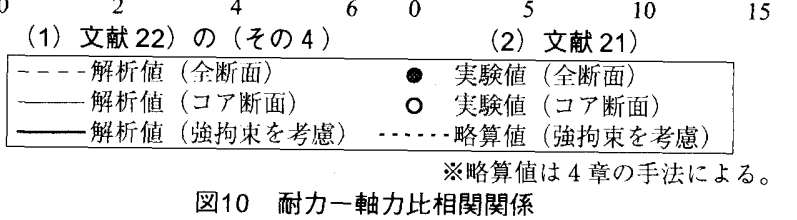

4. パラメトリックスタディと曲げ耐力略算法の提案

提案した強拘束コンクリートの応力ーひずみ関係を用いれば，高 軸力下においても柱の曲げ耐力を適切に評価できることを 3 章で述 べた。しかしながら，この手法は部材の高さ力向の耐力分布を求め て外力モーメントとの接点を求める必要があるため, 計算が煩雑で ある。また，耐力上昇に影響を及ぼす因子が明確でない。そこで, 4 章ではこの計算手法を用いてコア断面を対象としたパラメトリッ クスタディを行い, 曲げ耐力の上昇率 $M_{u} / M_{0}\left(M_{u}:\right.$ 材端の終局時 モーメント， $M_{0}$ : 強拘束領域を考慮しない場合の終局耐力。いずれ も図8参照）に影響を及ぼす因子を抽出する。また、これらを考虑し た簡便な曲げ耐力算定法を提案する。

4.1 パラメトリックスタディ

モデルケースとして表3に示す４ケースを設定した。断面寸法执よ び主筋配置は図11に示すとおりで，共通とした。また，曲げ耐力上 昇のメカニズムから， $M_{u} / M_{0}$ に影響を及ぼす可能性のある因子とし て, コンタリート強度 $f_{c}^{\prime}$, せ九断スパン比 $h / D$ ( $h$ : せん断スパ ン, $D:$ 柱のせい)，主筋比 $p_{g}$ および带筋比 $p_{w}$ を選定した。表3の モデルケースを基本として, 表4のうちの一つの因子を変動させて,

3 章で述べた手法により $M_{u} / M_{0}$ と軸力比 $n$ の相関を求めた。

表3のケース 2 を基準として $, h / D, f_{c}^{\prime} ， p_{g}$ および $p_{w}$ をそれぞ れ変動させた結果を, 軸力比 $n$ を横軸にして図12に示す。同図か ら， h/Dの影響が最も大きく， $f_{c}^{\prime}, p_{g}$ および $p_{w}$ の影響は比較的小 さいことが分かる。 $h / D$ の影響は危険断面の移動として現れるた め, 見かけの耐力上昇に大きく影響するものと推察される。なお, これらの結果はいずれのケースにも共通して見られた。

4.2 曲げ酎力略算法の提案

4.1節のパラメトリックスタディの結果から，せん断スパン比 $h / D$ が $M_{u} / M_{0}$ に及ぼす主要な因子であると捉え，これに着目して曲げ耐 力 $M_{u}$ の略算法を構築する。略算の手順を, 後に導出する数式ととも に示す (図13参照)。

(1)強拘束領域を考慮しない場合の終局耐力 $M_{0}$ と中立軸深さ $x_{n}{ }^{\prime}$ を 求める（通常の断面解析）。

(2)材端の終局酎力 $M_{e}$ を求める (式(7))。

(3)危険断面高さ $h_{c}$ を求める (式(8))。

(4)危険断面における終局耐力 $M_{c}$ を求好（式(13), 式(14)）。

表3 パラメトリックスタディに用いたモデル

\begin{tabular}{|c|c|c|c|c|c|}
\hline & \multirow{2}{*}{$\begin{array}{l}\text { コン夘ート強度 } \\
f_{c}\left(\mathrm{~N} / \mathrm{mm}^{2}\right)\end{array}$} & \multicolumn{2}{|c|}{ 主筋 } & \multicolumn{2}{|c|}{ 帯筋 } \\
\hline & & 配筋 & 鋼種 & 配筋 & 鋼種 \\
\hline 1 & 30 & \multirow{4}{*}{$12-\mathrm{D} 16$} & SD390 & D6果-@40 & SD345 \\
\hline 2 & 60 & & SD490 & D6-四-@40 & SD490 \\
\hline 3 & 100 & & USD685 & U6.4-田-@0 & SBPD1275/1420 \\
\hline 4 & 150 & & USD685 & U6.4-田-@0 & SBPD $1275 / 1420$ \\
\hline
\end{tabular}

断面寸法: $300 \times 300 \mathrm{~mm}$, せん断スパン: $450 \mathrm{~mm}$,

主筋比 $p_{g}: 2.7 \%$ ，帯筋比 $p_{w}: 1.0 \%$

表4 変数の設定

\begin{tabular}{c|c}
\hline$f_{c}\left(\mathrm{~N} / \mathrm{mm}^{2}\right)$ & $30 \sim 180(\underline{30}, \underline{60}, \underline{100}, \underline{150})$ \\
\hline$h / D$ & $1.0, \underline{1.5}, 2.0,2.5$ \\
\hline$p_{g}(\%)$ & $2.2, \underline{2.7}, 3.1,3.5$ \\
\hline$p_{w}(\%)$ & $0.5,0.8, \underline{1.0}, 1.2$ \\
\hline
\end{tabular}

※下線は基本とする値を示す。

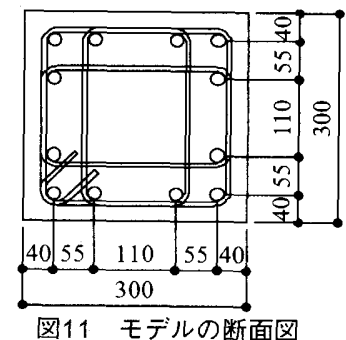


(5)材端の終局時モーメント $M_{u}$ を求める（式(15), 式(16)）。

これらを算定するための近似式を，パラメトリックスタディの結 果から導く。図7に示したように, 強拘束領域は材端における中立軸

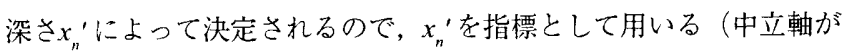
コア断面外にある場合はコア断面のせい $D^{\prime} に$ 読み替える）。また， モーメントは $M_{0}$ に対する上昇率 $M_{e} / M_{0}, M_{c} / M_{0}$ および $M_{u} / M_{0}$ で表現 し， $h_{c}$ および $x_{n}{ }^{\prime}$ は $D^{\prime}$ で無次元化して表す。

まず，(2)材端の終局耐力 $M_{e}$ を与える数式を導く。図14は $M_{0}$ に対す るMの上昇量と中立軸深さ $x_{n}{ }^{\prime}$ との関係を示している。式(2)拈よび式 (3)によれば，強拘束コンクリートの強度 $\sigma_{c m}^{\prime}$ と $f_{c}^{\prime}$ の差は式(6)に示す

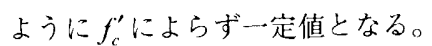

$$
\sigma_{c m}^{\prime}-f_{c}^{\prime}=\left(1+150 \frac{0.46}{f_{c}^{\prime}}\right) f_{c}^{\prime}-f_{c}^{\prime \prime}=69\left(\mathrm{~N} / \mathrm{mm}^{2}\right)
$$

したがって，同一の $x_{n}^{\prime} / D^{\prime} に$ に対する $M_{c}$ と $M_{0}$ の差も $f_{c}^{\prime}$ によらず概略一 定と見なせる。 $M_{0}$ が $f_{c}^{\prime} に$ に比例すると考えれば， $\left(M_{c}-M_{0}\right) / M_{0}$ は $f_{c}^{\prime \prime}$ 反比例することになるため, 図14の縦軸を $\left(M_{e} / M_{0}-1\right) f_{c}^{\prime}$ で表示し た。この指標と $x_{n}^{\prime} / D^{\prime}$ の関係は，同図中に示した四次関数で近似でき るので，材端の終局耐力Mは式(7)で求められる。

$$
\frac{M_{v}}{M_{0}}=\frac{120\left(x_{n}^{\prime} / D^{\prime}\right)^{4}}{f_{c}^{\prime}}+1
$$

次に(3)の危険断面成さ $h$ の算出式を導く。図15は $h$ と中点軸深さ $x_{n}^{\prime}$ の関倸を示している。网中の太い破線は，五面体で定手した強拘 束領域の頂点高さを小している。 $x_{n}^{\prime} / D^{\prime} か ゙$ 小さい場命，すなわち

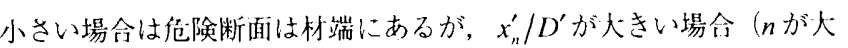
きい場合）は強拘束領域の頂点近傍に移動する。このときの，は $h / D$ により異なっている。これは，図8b)に示した耐力分布がいずれ のh/Dに対しても変化しないのに对し, 図8c)に示したモーメント分 布がh/Dにより変化するためである。危険断面が強拘集領域の頂点近 傍にあるときの高さは， $x_{n}^{\prime} / D^{\prime} の 一-$ 次関数として式(8)で表せる。

$$
\frac{h_{c}}{D^{\prime}}=a\left(\frac{x_{n}^{\prime}}{D^{\prime}}\right)+b \quad\left(\text { だし, } 0 \leq \frac{h_{c}}{D^{\prime}} \leq \frac{\sqrt{3}}{2} \frac{x_{n}^{\prime}}{D^{\prime}}\right)
$$

式(8)の傾きaと切片らは，図16および図17に示すように $f_{c}^{\prime 2}$ に比例 し，h/D'に反比例する傾问があり，式(9)一式(11)で近似できる。

$$
\begin{aligned}
a & =\frac{0.815}{h / D^{\prime}-1.12}\left(\frac{f_{c}^{\prime}}{150}\right)^{2}+\sqrt{3} / 2 \leftrightharpoons 0.8 A+\sqrt{3} / 2 \\
b & =\frac{-1.24}{h / D^{\prime}-1.10}\left(\frac{f_{c}^{\prime}}{150}\right)^{2} \fallingdotseq-1.2 A \\
\text { ここで, } A & =\frac{1}{h / D^{\prime}-1.1}\left(\frac{f_{c}^{\prime}}{150}\right)^{2}
\end{aligned}
$$

これらの式による計算結果を図15～図17内に点線で示す。なお，危 険断面が材端と五面体頂点の中間にある場合については定式化が困 難であるので, 中立軸が式(12)の $x_{n b}^{\prime}$ のときを境界とした二折れ線で 与えることとした。

$$
\frac{x_{n b}^{\prime}}{D^{\prime}}=\frac{-b}{a}
$$

次に, (4)危険断面における終局耐力 $M_{c}$ の推定式を検討する。パラ メトリックスタディの結果を図18に示す。危険断面が材端から離れ

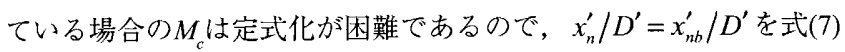
に代入して得られる值を用いることとした。

$$
\frac{M_{c}}{M_{0}}=\frac{M_{e}}{M_{0}}
$$$$
\left(\frac{x_{n}^{\prime}}{D^{\prime}}<\frac{x_{n b}^{\prime}}{D^{\prime}} \text { のとき }\right)
$$

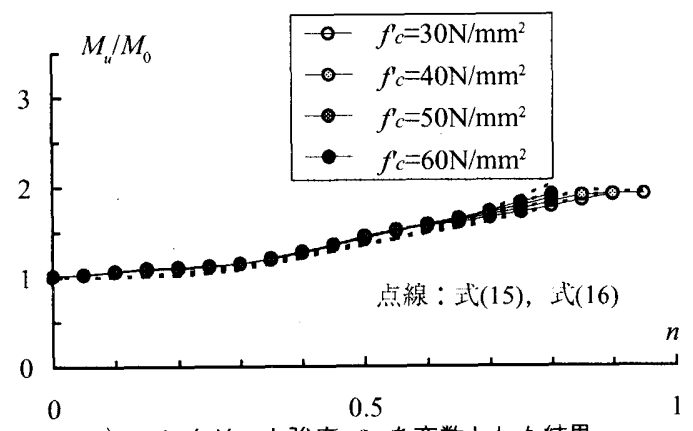

a）コンクリート強度 $f^{\prime} c$ を变数とした結果

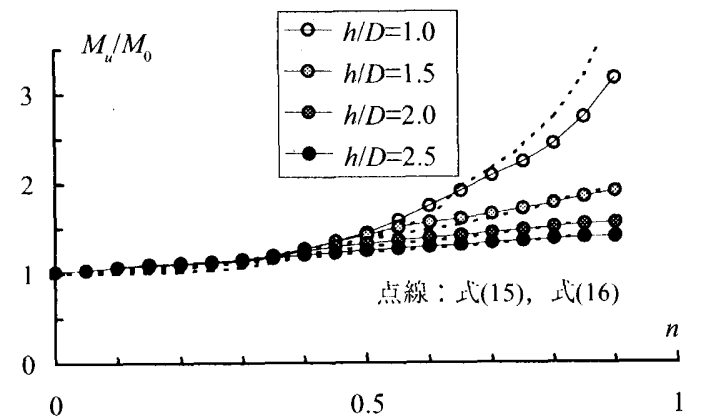

b）せん断スパン比 $h / D$ を変数とした結果

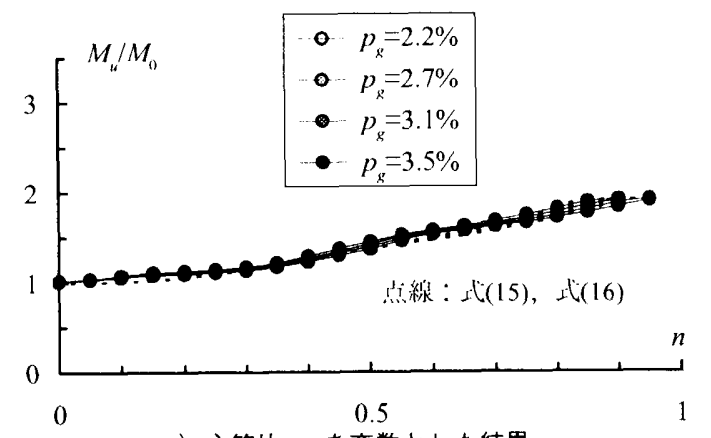

c）主筋比 $p_{g}$ を変数とした結果

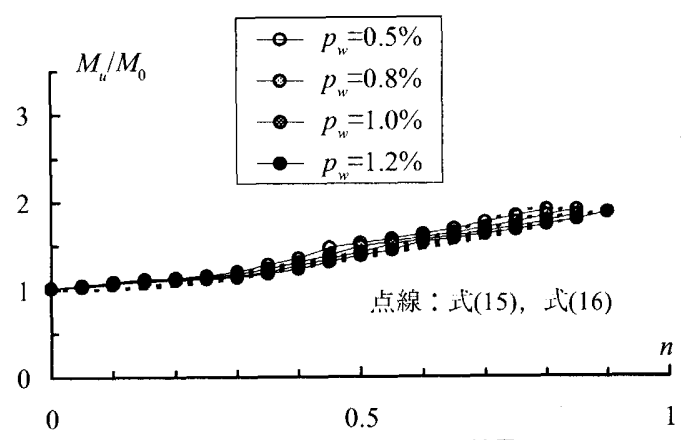

d）帯笳比 $p_{w}$ を変数とした結果

図12 曲げ耐力の上昇率 $M_{u} / M_{0}$ と軸力比 $n$ の関係 (ケース2 $\left(f^{\prime} c=60 \mathrm{~N} / \mathrm{mm}^{2}\right)$ の計算結果 $)$

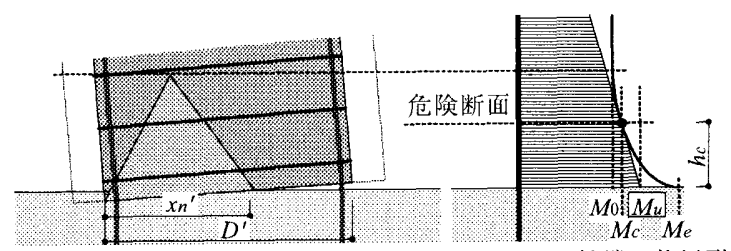

$M_{0}$ ：強拘束領域を考慮しない場合の終局耐力, $M_{e}$ ：材端の終局耐力 $M_{c}$ ：危険断面の終局耐力, $M_{u}$ : 材端の終局時モーメント

図13曲げ耐力算定の概念図 

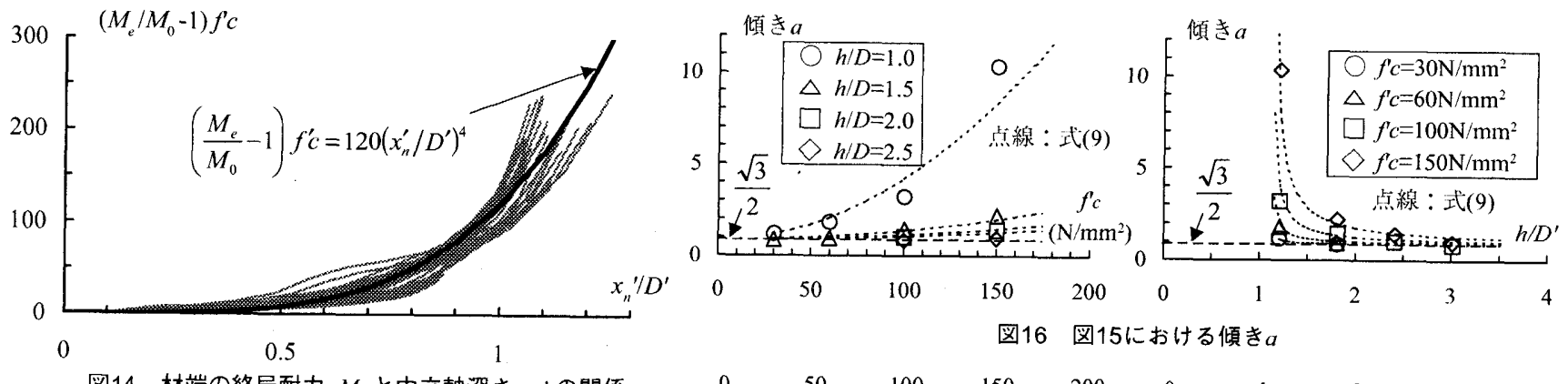

図14 材端の終局耐力 $M_{e}$ と中立軸深さ $x_{n}$ 'の関係

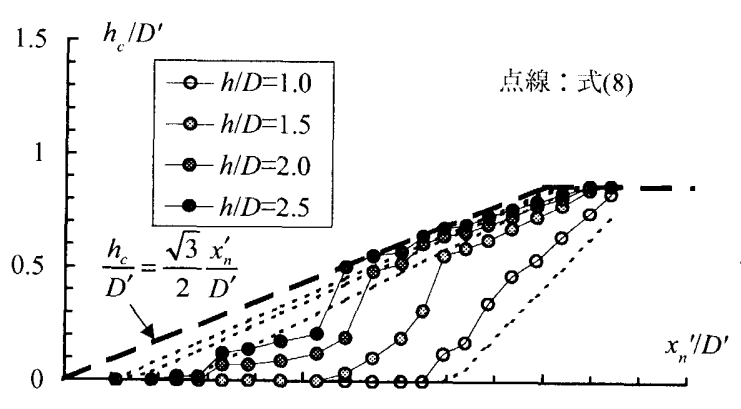

0

図15 危険断面高さ $h_{c}$ と中立軸深さ $x_{n}$ 'の関係

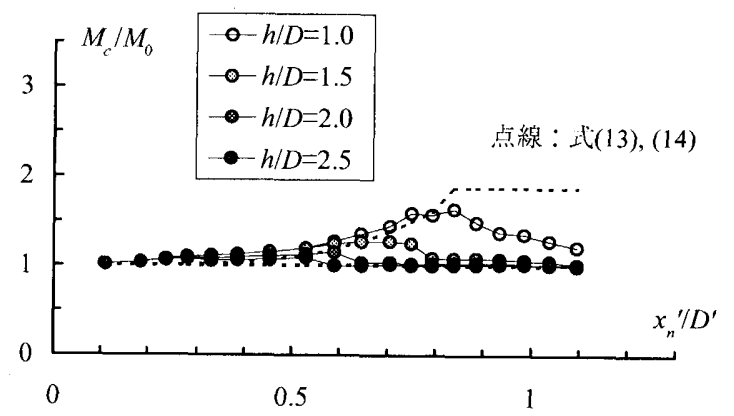

図18危険断面における終局耐力 $M_{c}$ と中立軸深さ $x_{n}{ }^{\prime}$ の関係

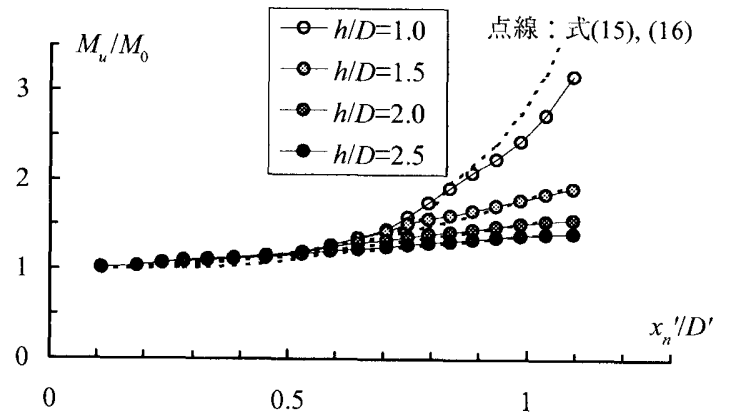

図19 材端の終局時モーメント $M_{u}$ と中立軸深さ $x_{n}^{\prime}$ の関係

$$
\frac{M_{c}}{M_{0}}=\frac{120\left(x_{n b}^{\prime} / D^{\prime}\right)^{4}}{f^{\prime} c}+1 \quad\left(\frac{x_{n}^{\prime}}{D^{\prime}} \geq \frac{x_{n b}^{\prime}}{D^{\prime}} \text { のとき }\right)
$$

(5)材端の終局時モーメント $M_{u}$ は式(15)および式(16)で求められる。

$$
\begin{array}{ll}
\frac{M_{u}}{M_{0}}=\frac{M_{c}}{M_{0}}\left(=\frac{M_{e}}{M_{0}}\right) & \left(\frac{x_{n}^{\prime}}{D^{\prime}}<\frac{x_{n b}^{\prime}}{D^{\prime}} \text { のとき }\right) \\
\frac{M_{u}}{M_{0}}=\frac{M_{c}}{M_{0}} \frac{h / D^{\prime}}{h / D^{\prime}-h_{c} / D^{\prime}} & \left(\frac{x_{n}^{\prime}}{D^{\prime}} \geq \frac{x_{n b}^{\prime}}{D^{\prime}} \text { のとき }\right)
\end{array}
$$

図190横軸を軸力比 $n$ に置き換えたのが図12b)である。

式(7)～式(16)による略算結果を図12内に点線で示した。また，3 章で扱った実験值と略算値の比を図20に示すとともに，軸力比との

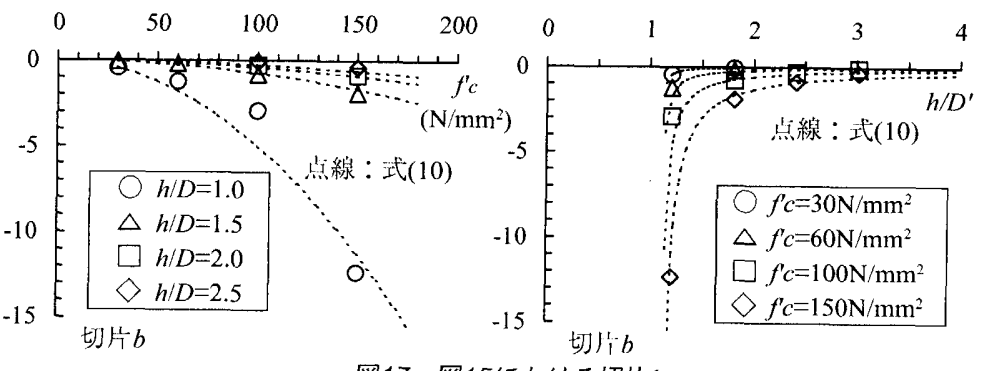

図17 図15における切片b
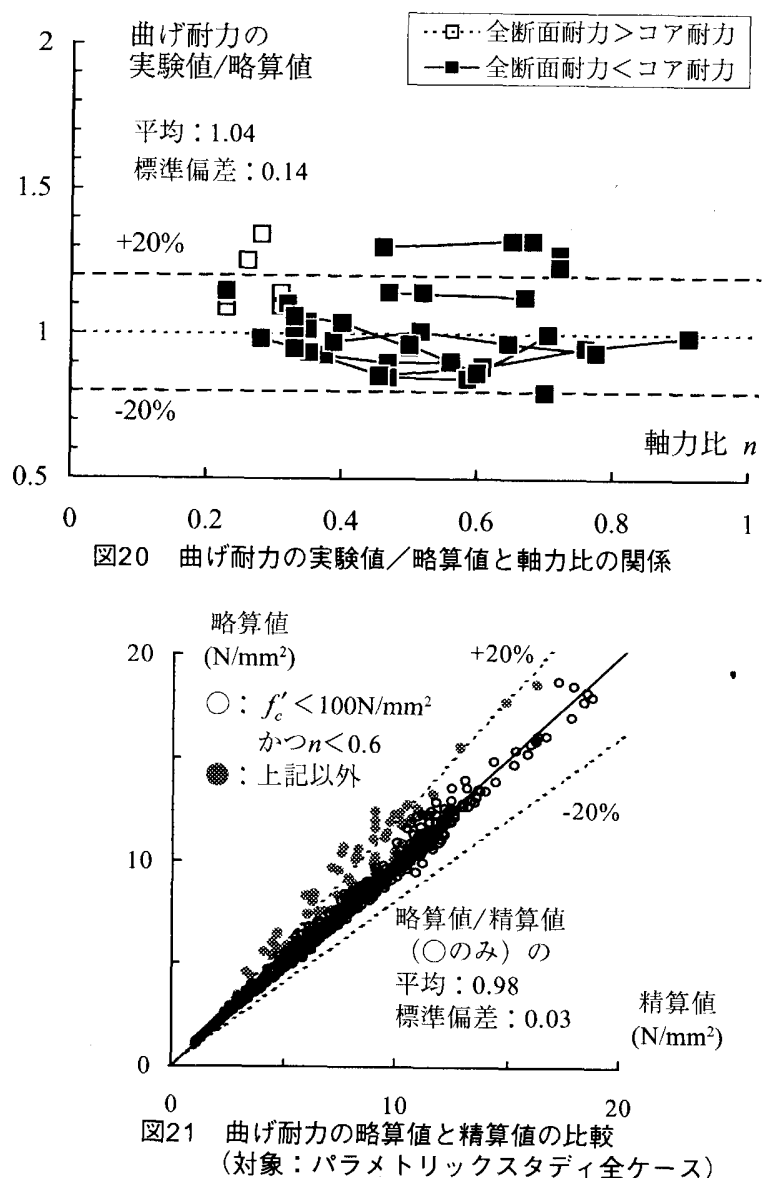

相関関係を前揭の図10内に示す。さらにパラメトリックスタディ を行った全ケースについて略算值と精算值を比較して図21に示す (いずれも平均せん断応力)。略算法は, $f_{c}^{\prime} か ゙ 100 \mathrm{~N} / \mathrm{mm}^{2}$ 以上の超 高強度コンクリートを用い, かつ軸力比 $n$ が 0.6 以上の高軸力を作 用させた場合については若干過大に評価しているが，他の場合につ いては精算結果と同等の値が得られており（図21），実験結果との 整合性も良好である（図20）。本節で示した簡便化はおおむね妥当 であったと判断できる。この方法は, 通常の断面解析による耐力値 
$M_{0}$ とそのときの中立軸深さ $x_{n}{ }^{\prime}$ が与えられれば, 前述の(1) (5)の手 順により強拘束領域を考慮した曲げ酎力を簡便に算定でき, 部材の 上限強度を求める有効な手段となりうると考えられる。

\section{5.まとめ}

$\mathrm{RC}$ 柱の曲げ耐力の算定法について，柱端部コンクリートの圧縮特 性に着目した検討を行った。その概要と得られた結果を述べる。

1. 部材内コンクリートを, 三軸応力を受ける強拘束領域と周辺領域 に領域分けする概念を示し, 高さ/直径の異なるシリンダー供試 体の圧縮実験結果から強拘束コンクリートの応力ーひずみ関倸を 推定した。

2.「1.」で設定した応力ーひずみ関倸をストレスブロックに置換し て平面保持解析により曲け耐力を算定し，実験結果との比較によ りその妥当性を確認した。柱端部の強拘束コンクリートを考虑 し，危険断面の移動を想定することにより，高軸力下の曲げ耐力 実験結果が通常の曲け解析結果を大きく上回る現象を説明するこ とができる。

3.「2.」の曲げ耐力算定法を用いてパラメトリックスタディを行 い，耐力上昇は軸力比とせん断スパン比の影響を強く受けること を把握した。また，これを考慮でき，精度良く曲げ耐力を算定し うる略算法を提案した。本手法は, 部材の上限強度を求める有効 な手段となりうると考えられる。

なお，本論文では剛強な加ノスタブを有する柱試験体による実験絬果に 基づいて検討を行った。実際の建物では，基礎に接続する柱がこれと闬 等の拘束条件であり，他の柱ではこれょり拘束条件が少ると考えられ る。しかしながら，端面の拘束条件を種々設定した柱の実験により，率 辺に梁と床スラブの取り付く柱の曲げ性状は剛強なスタブ付きの場合と 明確な差異がないとの報告がなされている2k)ことから，本論文で検㗅 した曲け耐力算定法はこれらの柱にも適用しうると考えている。

\section{参考文献}

1) A. B. Ghee, M. J. N. Priestley and T. Paulay: Seismic Shear Strength of Circular Reinforced Concrete Columns, ACI Structural Journal, Vol.86, No.1, pp.45-59, Jan.-Feb. 1989

2）日本建築学会：鉄筋コンクリー上造建物の勒性保証型設計指針・可解説， 1999 年 8 月

3）建設省総合技術開発プロジェクト：鉄筋コンクリート造建築物の超軽量 化·超高層化技術の開発 平成 4 年度高強度鉄筋分科会コンファインドコ ンクリートWG 報告書, 1993 年 3 月

4) H. Tanaka, R. Park and B. McNamee : Anchorage of Transverse Reinforced Concrete Columns in Seismic Design, Bulletin of the New Zealand National Society for Earthquake Engineering, Vol.18, No.2, June, pp.165-190, 1985

5）㻕田久人，曹胃栍：コンクリートの三軸応力ーひずみ特性を考虑した鉄筋 コンクリート部材の) 三次儿有限要素曲げ強度解析, 日本建築学会構造系論 文集，第 530 号，pp.115-121，2000年 4 月

6）滝口克己, 堀出久人, 满测知已, 森田修平：RC 柱端部コンクリートの压 稆特性に関する基礎垁験，日本建築学会構造系諭文報告集，第 442 号, pp.123-131，1992 年12月

7）滰口克己，森田修平：偏心圧縮を受ける $\mathrm{R} / \mathrm{C}$ 部材におけるコンクリートの 压縮挙動，日本建築学会構造系論文集，第464号, pp.109-118，1994 年10月

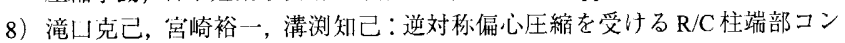
クリートの王縮特性, 日本建築学会構造系論文集, 第478号, pp.143-151,
1995 年. 12 H

9）滝门克己，今井和正，清测知已：下縮曲げせん断を受ける R/C 柱端部コン

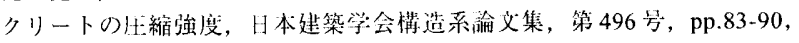
1997 年: 6 月

10) E. Hognestad : A STUDY OF COMBINED BENDING MOMENT AND AXIAL LOAD IN REINFORCED CONCRETE MEMBERS, UNIVERSITY OF ILLINOIS ENGINEERING EXPERIMENT STATION, Bulletin Series No.399, 1951

11) American Concrete Institute : Building Code and Commentary ACI 318-95/ 318R-95, 1995

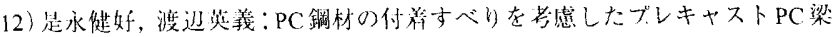

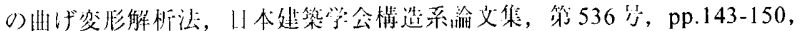
2000 年 10 J

13) J. W. Murdock and C. E. Kesler : Effect of Length to Diameter Ratio of Specimen on the Apparent Compressive Strength of Concrete, ASTM Bulletin, No.221, pp.68-73, 1957

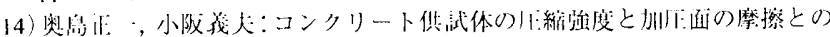

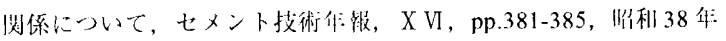

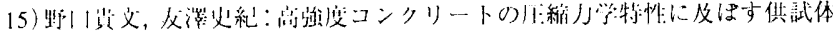

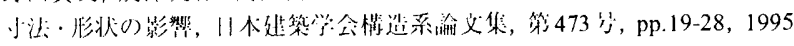
代 7 H

16) H. Hotta and C. G. Cho: Three-Dimensional Finite Element Analysis on Compressive Strength of Concrete Prisms with Several Height/Width Ratios,

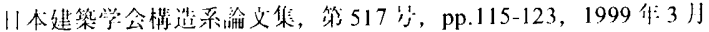

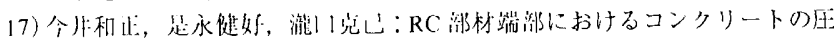

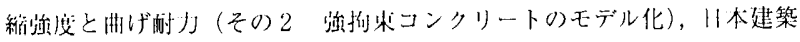

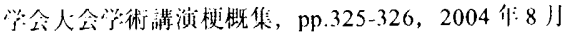

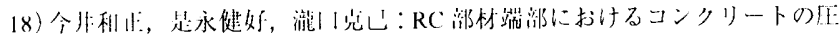

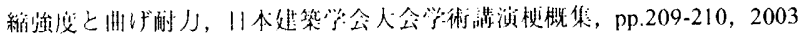
位: 9 J

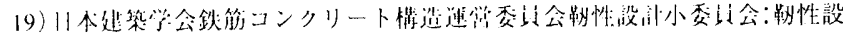

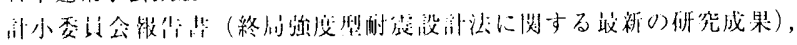
pp. 20-21，1992 位: 8 打

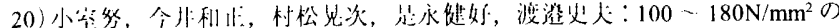

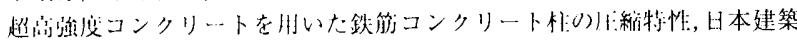

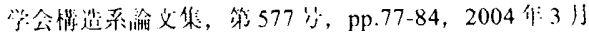

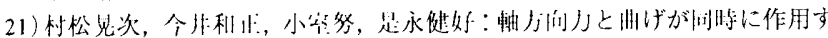

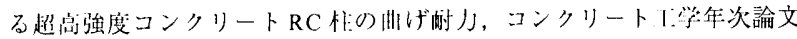
位, 第 26 卷, pp.811-816，2004 隹: 7 小

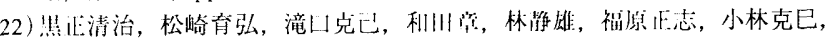
枝達夫:高軸力下に扔ける鉄筋コンクリート朴の耐震性能の評体に関す

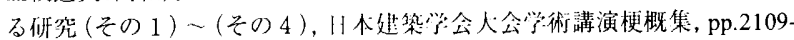
2116 , 昭和 58 作 9 月

23）四村彰男，菅野俊介，長嶋俊雄，木村秀樹，原誠，沢村牧人：超高層鉄筋 コンクリート造建物の柱㧍よび架構に関する実験的研究（その5）高軸 生科力を受ける溶接金網柱の曲げせん断実験, 日本建築学会大会学術講演 梗概集, pp.151-152, 昭和 61 年 8 H

24）金出和宏，黑刐健嗣：高軸力を受ける高強度 $\mathrm{RC}$ 柱の弾塑性性状，コンク リート工学年次論文報告集，第 12 巻， 2 号，pp.411-416，1990 年

25）黄楷，李康寧，壁谷澤寿海：高軸力を受ける高強度鉄筋コンクリート柱の 強度と变形性能に関する実験的研究，コンクリートT学年次論文報告集， 第 12 卷, 2 号, pp.427-432, 1990 年

26）小室努，是永健好，竹崎真 ·，川端……超高強度材料を用いた $\mathrm{RC}$ 柱の 構造性能 (その) 1 実験計画抢よび尖験絡喿概姴)，(その 2 実験結果の 検討)，甘本建築学会大会学術講演梗概集，pp.37-40，1997年 9 月

27) 六車熙, 渡辺史夫，罘清水隆，光枝良：横補強による宫強度コンクリート のじん性改善に関する研究, 第5 回コンクリート丁学年次講演会講演論文 集, pp.317-320, 1983 年.

28）堀田久人，香川賢次，滝口克己：尖構造物を模した端部境界条件を有する $\mathrm{RC}$ 造柱の曲げ強度及び変形性能に関する研究, 日本建築学会構造系論文 集，第 559 号，pp.197-204，2002 年 9 月

(2004年 6 月 10 日䅫稿受理，2004年10月13日採用決定 